\title{
IMPLEMENTASI NILAI-NILAI CORPORATE CULTURE PADA KARYAWAN BANK SYARIAH (STUDI BANK BJB SYARIAH KC BOGOR)
}

\section{IMPLEMENTATION OF CORPORATE CULTURE VALUES IN SHARIA BANK (STUDI OF BJB SYARIAH BANK)}

\section{Aditya Darmawan1a; Furqonul Haq²; Afiaty Kurniasih ${ }^{3}$}

\author{
1aProgram Studi Perbankan Syariah Fakultas Ekonomi Islam Universitas Djuanda, \\ Jl. Tol Ciawi No. 1, Kotak Pos 35 Bogor 16720, e-mail: aditd5150@gmail.com \\ 2Program Studi Ekonomi Syariah Fakultas Ekonomi Islam Universitas Djuanda, \\ Jl. Tol Ciawi No. 1, Kotak Pos 35 Bogor 16720 \\ 3Program Studi Perbankan Syariah Fakultas Ekonomi Islam Universitas Djuanda, \\ Jl. Tol Ciawi No. 1, Kotak Pos 35 Bogor 16720
}

\begin{abstract}
This study aims to find out what are the values of the corporate culture at BJB syariah bogor branch office and how the implementation ofvalues corporate culture in employees of bank bjb syariah bogor branch office. This study uses descriptive qualitative research methods that describe the objects in the form of oral and written from the speakers and observed behavior in order to obtain the data needed. Based on the results of research conducted that the cultural values of BJB syariah bogor branch office namely MASLAHAH are Militant, Trustworthy, Solutions, Services, Harmony and Holistic which have been applied to employees through socialization conducted from the beginning of the selection of prospective employees and also employees who have worked in the company. Not only that socialization was also carried out with the existence of pocket books which were used as guidelines in behaving, then these values were manifested in the daily activities of the employees. The application of corporate culture values to the employees of BJB syariah bogor branch office has been quite good, so that it has an impact on the daily lives of the employees in the office to be more enthusiastic, more disciplined and responsible, have good relationships between employees and good relations with employers, increased trust and loyalty customer for BJB syariah bogor branch office
\end{abstract}

Keywords: Corporate Culture and Implementation

\begin{abstract}
ABSTRAK
Penelitian ini bertujuan untuk mengetahui apa saja nilai-nilai corporate culture pada Bank BJB Syariah KC Bogor dan bagaimana implementasi nilai-nilai corporate culture pada karyawan Bank BJB Syariah KC Bogor. Penelitian ini menggunakan metode penelitian deskriftif kualitatif yang menggambarkan tentang objek berupa lisan maupun tulisan dari narasumber dan perilaku yang diamati guna mendapatkan data-data yang diperlukan. Berdasarkan hasil penelitian yang dilakukan bahwa nilai-nilai budaya pada Bank BJB Syariah KC Bogor yaitu MASLAHAH Militan, Amanah, Solusi, Layanan, harmoni dan Holistik yang mana secara keseluruhan telah diterapkan pada karyawan melalui sosialisasi yang
\end{abstract}


dilakukan sejak awal pemilihan calon karyawan dan juga pada karyawan yang sudah bekerja diperusahaan. Tidak hanya itu sosialisasi juga dilakukan dengan adanya buku saku yang dijadikan pedoman dalam berperilaku, kemudian nilai-nilai tersebut diwujudkan dalam kegiatan sehari-hari para karyawan. Penerapan nilainilai budaya perusahaan pada karyawan Bank BJB Syariah KC bogor sudah cukup baik., Sehingga berdampak pada keseharian para karyawan dikantor jadi lebih semangat, lebih disiplin dan tanggung jawab, memiliki hubungan baik antar karyawan serta hubungan baik dengan atasan, meningkatnya kepercayaan dan loyalitas nasabah terhadap Bank BJB Syariah KC Bogor.

Kata kunci : Corporate Culture dan Implementasi

M. Aditya Darmawan. 2019. Implementasi Nilai-Nilai Corporate Cultue Pada Karyawan Bank Syariah. Nisbah: Jurnal Perbankan Syariah 5 (1): 19-29.

\section{PENDAHULUAN}

Hasil riset menunjukan bahwa nilai dalam budaya organisasi sangat mempengaruhi motivasi para anggota dalam bekerja. seseorang dapat menjalankan fungsinya secara efektif dalam suatu organisasi, seseorang perlu tahu bagaimana mengerjakan sesuatu termasuk bagaimana berperilaku sebagai anggota organisasi, khususnya dalam lingkungan organisasinya. Budaya organisasi yang jelas akan membuat karyawan mengerti aturan main yang harus dijalankan, baik dalam mengerjakan tugasnya, maupun dalam berinteraksi dengan sesama anggota dalam organisasi. Ketidakraguan dalam menjalani hal ini akan membawa peneguhan bagi seseorang, yang membuatnya mengerti apa yang harus dan tidak boleh dilakukan. Budaya akan meningkatkan komitmen organisasi dan meningkatkan konsistensi dari perilaku karyawan. Dari sudut pandang karyawan, budaya memberitahu mereka bagaimana segala sesuatu dilakukan dan apa yang penting (Gea, 2005: 326). Selain untuk meningkatkan kontsistensi perilaku karyawan, penguatan budaya perusahaan dilakukan oleh sektor organisasi publik. Salah satu sektor organisasi publik yang memiliki budaya perusahaan dan memperkuatnya adalah Bank Indonesia.

Hasil riset dan lembaga yang meneliti tentang budaya perusahaan dan hasilnya berdampak positif terhadap kinerja perusahaan. Namun istilah budaya perusahaan atau Corporate Culture setiap Bank Syariah tidak semua sama, hal ini bisa dilihat dari kebijakan internal Bank Syariah yang merumuskan budaya perusahaan, salah satunya termuat dalam peraturan disiplin perusahaan dan kode etik perusahaan, maka dari itu penulis ingin melihat bagaimana teori Corporate Cultutre dan bagaimana penerapannya dalam versi bank Syariah.

\section{MATERI DAN METODE}

Budaya perusahaan (Corparate Culture) merupakan aplikasi dari budaya organisasi (organizational culture) terhadap badan usaha atau perusahaan. Kedua istilah ini sering dipergunakan untuk maksud yang sama secara bergantian (Ndraha, 2003: 4). Perusahaan terdiri dari 
berbagai elemen terintegrasi dan dibentuk oleh budaya yang lebih besar. Budaya perusahaan dibangun untuk mengatasi tantangan di masa yang lalu. Berbagai kebijakan, prosedur, filosofi perusahaan, kebiasaan dan lain-lain merupakan resiko terhadap situasi dan tantangan dimasa yang lalu (Vasquez \& Gonjales, 2015: 53).

Budaya perusahaan merupakan bagian dari lingkungan internal yang tidak terpisahkan dari perusahaan yang terdiri dari seperangkat asumsi, keyakinan, dan nilai yang dianut bersama oleh anggota organisasi yang digunakan untuk mengatur serta mengarahkan perilaku sesuai dengan fungsi yang diharapkan (Gordon, 2002: 374) dengan demikian, budaya perusahaan bagaimana anggota organisasi seharusnya berprilaku dengan membangun sistem nilai yang disampaikan dengan tatacara, ritual, mitos, legenda, dan berbagai aktivitas lainya.

Budaya perusahaan Islam merupakan sebuah nilai yang diambil dan dikembangkan untuk diterapkan dalam kehidupan sehari-hari atau kegiatan dengan menggunakan nilainilai Islam yang sesuai dengan pedoman Islam yaitu Alqu'an dan Hadits (Hakim, 2012: 32). Budaya perusahaan Islam yang dilakukan akan menimbulkan perspektif Islam di dalam budaya tersebut agar memberikan dasar atau pijakan yang dapat menjadikan bentuk serta cara yang perlu diselenggarakan secara kolektif melalui suatu Organisasi menjadikan seruan atau ajakan kepada seseorang (pemimpin) untuk mengikuti ajaran dan aturan yang ada di dalamnya, seperti firman Allah SWT dalam Q.S Ali' Imran (3:110):

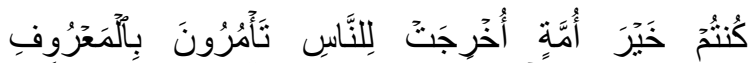

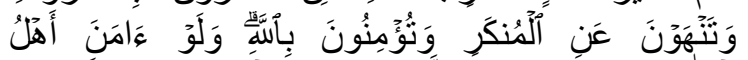

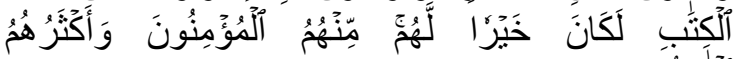

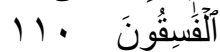

Artinya: Kamu adalah umat yang terbaik yang dilahirkan untuk manusia, menyuruh kepada yang ma'ruf, dan mencegah dari yang munkar, dan beriman kepada Allah. Sekiranya Ahli Kitab beriman, tentulah itu lebih baik bagi mereka, di antara mereka ada yang beriman, dan kebanyakan mereka adalah orang-orang yang fasik (Q.S Ali' Imran 3: 110).

Konsep dasar yang menjadi landasan ekonomi Islam dapat dijadikan landasan budaya kerja sebagai budaya perusahaan yang Islami. Budaya perusahaan yang Islami tersebut antara lain didasarkan pada tiga konsep fundamental, yaitu tauhid (keimanan kepada Allah), khilafah (kepemimpinan), dan a'dalah (keadilan). (Lukman Hakim, 2011).

Karakteristik budaya perusahaan islami dibangun dari beberapa faktor penting didalam perusahaan tersebut diantanya: Pemimpin Islami, bekerja merupakan ibadah, bekerja dengan azas manfaat dan maslahat, dan bekerja dengan mengoptimalkan kemampuan akal. Budaya suatu organisasi dibangun dan dipertahankan budaya asli diturunkan dari filosofi pedomannya dan sangat mempengaruhi kriteria untuk mempekerjakan karyawan. Selanjutnya, tindakan manajemen puncak akan menentukan iklim umum dari perilaku yang dapat diterima bagaimana karyawan harus disosialisasikan tergantung pada keberhasilan dalam mencocokan nilainilai karyawan baru dengan nilai-nilai organisasi dari proses seleksi maupun preferensi manajemen puncak terhadap metode sosialisasi.

Dari sisi fungsi, budaya perusahaan mempunya beberapa 
peran yaitu: (Widuri \& Paramita, 2007: 34)

a. Budaya mempunyai suatu peran pembeda. Hal itu berarti bahwa budaya organisasi menciptakan pembedaan yang jelas antara satu organisasi dengan organisasi lainnya.

b. Budaya organisasi membawa suatu rasa identitas bagi anggota organisasi.

c. Budaya organisasi mempermudah timbul pertumbuhan komitmen pada suatu yang lebih luas dari pada kepentingan dari individual.

d. Budaya korporat itu meningkatkan pemantapan sistem sosial

Hubungannya dari segi sosial, budaya menurut Gordon berfungsi sebagai perekat sosial yang membantu mempersatukan organisasi itu dengan memberikan standar yang tepat untuk apa yang harus dikatakan dan dilakukan oleh para karyawan. Akhirnya budaya berfungsi sebagai mekanisme pembuat makna kendali yang memandu dan membentuk sikap serta perilaku para karyawan budaya korporat yang efektif tercermin pada kepercayaan, keterbukaan, komunikasi, kepemimpinan yang dapat masukan (considerate), dan didukung oleh bawahan (supportive), pemecahan masalah oleh kelompok, kemandirian kerja, dan pertukaran informasi.

Fungsi budaya perusahaan yaitu sebagai perekat sosial dalam mempersatukan karyawan dalam suatu perusahan dan juga merupakan suatu ketentuan, peraturan yang terdiri dari nilai-nilai, norma-norma dan kepercayaan yang dijadikan acuan dalam bertindak oleh karyawan untuk mencapai tujuan dan keberlangsungan perusahaan.

\section{Metodologi Penelitian}

Jenis penelitian yang dilakukan adalah penelitian deskriptif kualitatif dengan pendekatan fenomenologi.
Fenomenologi yang berusaha untuk memahami kejadian dari pengalaman hidup beberapa orang tentang suatu konsep yang akan diteliti menjadi acuan dalam mengolah data yang diperoleh dari lapangan, sehingga pembuatan kesimpulannya akan lebih tertata jelas dan lengkap. Fokus fenomenologi bukan pengalaman partikular, melainkan struktur dari pengalaman kesadaran yakni realitas obyektif. Fenomenologi berfokus pada makna subyektif dari realitas obyektif di dalam kesadaran seseorang yang menjalani aktivitas kehidupannya sehari-hari (Hajaroh, 2005: 13).

\section{HASIL DAN PEMBAHASAN}

Budaya perusahaan erat kaitannya dengan pemberdayaan karyawan disuatu perusahaan. Semakin kuat budaya perusahaan, maka semakin besar dorongan setiap karyawan untuk maju bersama dengan perusahaan. Berdasarkan hal tersebut penerapan dan pengembangan budaya dalam suatu perusahaan sangat diperlukan dalam rangka membangun perusahaan yang efektif dan efisien sesuai dengan visi dan misi hendak dicapai.

Menurut Suprayogi implementasi pada hakikatnya adalah upaya pemahaman apa yang terjadi setelah sebuah program dilaksanakan. Merujuk pada tahapan implementasi yang dikemukakan oleh yaitu tahapan interpretasi, tahapan pengorganisasian dan tahapan implikasi. (Pratama \& Dihan, 2017).

\section{Interpretasi}

Merupakan tahapan penjabaran sebuah kebijakan yang bersifat abstrak dan sangat umum ke dalam kebijakan atau tindakan yang bersifat manajerial dan operasional. Kegiatan dalam tahap ini tidak hanya berupa proses penjabaran dari kebijakan abstrak ke 
petunjuk pelaksana, namun juga berupa proses komunikasi dan sosialisasi kebijakan tesebut, baik yang berbentuk abstrak maupun operasional.

\section{a. Penjabaran Budaya Organisasi/ \\ Perusahaan}

Budaya perusahaan pada Bank BJB Syariah KC Bogor memiliki beberapa nilai yang disingkat dengan kata MASLAHAH (Militan, Amanah, Solusi, Layanan, Harmoni dan Holistik) yaitu sesuatu yang mendatangkan kebaikan, manfaat, faidah atau kegunaan. Penjabaran nilai tersebut tentu sudah dijabarkan pada halaman sebelumnya yang membahas butirbutir nilai yang ada pada bank BJB Syariah KC Bogor. Nilai-nilai yang ada tidak hanya didapatkan dari sumber buku dan jurnal tetapi nilai tersebut didapatkan dari sumber langsung dalam perusahaan.

Nilai-nilai budaya perusahaan yang ada pada bank BJB Syariah KC Bogor yaitu MASLAHAH (militan, amanah, solusi, layanan, harmoni, dan holistik) nilai milita dapat dilihat dari semangat dan berdedikasi penuh pengabdian, tidak kenal lelah, mengeluarkan kemampuan terbaik. Nilai amanah yaitu memiliki sikap mental yang di dalamnya terkandung unsur kepatuhan terhadap hukum, tanggung jawab terhadap tugas, kesetiaan terhadap komitmen, keteguhan dalam memegang janji dan mempunyai integritas, nilai solusi kemampuan untuk memberikan jalan keluar, penyelesaian dan pemecahan masalah, nilai layanan memiliki daya tarik, menyenangkan dalam berprilaku baik ke nasabah, tamu, rekan, dan mitra dalam memberi pelayanan yang terbaik sesuai atau melebihi harapan sehingga mereka merasa sangat puas. Nilai harmoni yang terciptanya keselarasan, kombinasi antar bagian, kekeluargaan dan menjaga silaturahmi. Nilai holistik yaitu dapat dilihat dengan adanya cara pandang yang menyatakan bahwa keseluruhan sebagai satu kesatuan lebih penting dari pada bagian-bagiannya karena kekuatan ada pada kebersamaan kita.

Nilai-nilai budaya perusahaan yang disebutkan diatas sudah cukup dipahami dan dimengerti oleh Karyawan Bank BJB Syariah KC Bogor, karena dengan adanya nilainilai tersebut dapat memotivasi dan menjadi acuan karyawan dalam hal kinerja maupun perilaku agar sesuai dengan nilai-nilai budaya perusahaan yang ada. Sebelum nilai-nilai tersebut dipahami oleh semua karyawan tentu perlu adanya metode penerapan budaya perusahaan salah satunya yaitu sosialisasi, yang mana karyawan mempelajari seluk beluk perusahaan serta bagaimana mereka harus berinteraksi dan berkomunikasi antar sesama karyawan untuk menjalankan seluruh aktivitas perusahaan.

Selain itu pemimpin perusahaan juga harus mampu melaksanakan kegiatan sosialisasi budaya pada karyiawannya, agar proses sosialisasi memberi dampak positif pada produktivitas, komitmen, serta turnover karyawan tersebut. Pada akhirnya implementasi budaya perusahaan akan mendukung dan mendorong karyawan untuk mencapai sasaran yang diinginkan perusahaan.
b. Sosialisasi
Budaya
Organisasi/

\section{Perusahaan}

Mengenai proses sosialisasi yang menjadi bagian penting dari penerapan nilai-nilai budaya tersebut, peneliti menemukan adanya beberapa tahapan sosilalisasi yang sesuai dengan teori yang dikemukakan oleh Luthans, pertama, penilaian sejak awal pemilihan calon karyawan, apakah ia mampu menerima budaya perusahaan atau bahkan dapat mengubah budaya yang ada yang kedua, menerima tupoksi kepada 
karyawan sesuai dengan skill-nya masing-masing, ketiga, diadakannya pendalaman bidang pekerjaan yang dilakukan dengan tes tulis maupun tes secara langsung dilapangan. Keempat penilaian kinerja serta pemberian penghargaan pada karyawan, terakhir, menanamkan kesetiaan pada nilai budaya dengan diberikannya sanksi bagi karyawan yang tidak mengikuti peraturan. Berdasarkan hasil wawancara proses tahapan sosialisasi budaya perusahaan dilakukan dengan beberapa tahap. Pertama dilakukan sejak awal pemilihan calon karyawan, apakah karyawan tersebut sudah sesuai dengan kriteria yang diharapkan dan dapat menerima budaya yang ada pada perusahaan. Kedua, karyawan akan diberikan pendalaman pekerjaan sesuai dengan tupoksinya agar karyawan dapat memahami tugas dan tanggung jawabnya, yang mana dilakukan pelatihan, e-learning dan learning program. Ketiga, ada bagian kontrol budaya perusahaan, kontrol dari internal yaitu change agent dari divisi budaya perusahaan. Adanya evaluasi yang dilakukan oleh konsultan yang dinamakan LENTERA, yang mana konsultan tersebut menilai tampilan gedung, kebersihan, pelayanan, busana, parkiran dan lain sebagainya yang berkaitan dengan budaya perusahaan. Kelima, dilakukan pemantapan terhadap nilai-nilai budaya perusahaan yang dileselenggarakan kantor pusat, penilaian tersebut ada yang berbentuk tes tulis dan ada juga dilakukan langsung dilapangan. kemudian jika ada karyawan yang tidak melaksanakan nilai-nilai budaya tersebut akan dikenai sanksi berupa teguran, surat peringatan, panggilan, dan surat pernyataan".
Proses sosialisasi memberikan manfaat dalam menerapkan budaya perusahaan yang terkandung dalam nilai-nilai budaya sebagai pedoman perilaku bagi setiap karyawan manfaat yang terkandung adalah proses penerapan budaya perusahaan akan berjalan dengan baik karena disosialisasikan sejak awal pemilihan calon karyawan hingga karyawan tersebut bekerja pada perusahaan dan juga melalui pembuatan buku saku yang didalamnya terdapat halhal yang boleh dilakukan dan apa yang tidak boleh dilakukan sehingga hal tersebut dapat membentengi karyawan dalam bekerja dan berperilaku.

Adanya phunismentyang sudah disosialisasikan dengan baik, dapat mengurangi jumlah karyawan yang melanggar nilai-nilai yang ada, ketika suatu peraturan disosialisasikan budaya perusahaan juga dapat dilakukan dengan memberikan pelatihan tentang model budaya perusahaan yang digunakan untuk mengetahui bagaimana karyawan mengenal budaya yang ada pada perusahaannya melalui pengetahuan anggota organisasi tentang artefak, seperti bahasa sehari-hari, seragam, makna logo perusahaan dan lain-lain. Selain artefak terdapat nilai-nilai yang menjadi pedoman perilaku dan asumsi dasar yang digunakan oleh seorang pemimpin dalam mengambil keputusan. Berdasarkan hasil wawancara dengan informan 3 sebagai berikut:

"Mengenai model budaya perusahaan seperti artifak, rancangan gedung tidak mengandung makna apa-apa. Kalau bahasa yang digunakan di sini berasal dari jawa barat. Untuk logo perusahaan lebih jelasnya saya kurang begitu hafal".

Berdasarkan percakapan yang diungkapkan oleh bapak gumilar 
diatas dapat ditarik kesimpulan bahwa pembahasan mengenai model budaya perusahaan pada bank BJB Syariah KC Bogor belum terlalu dipeajari secara mendalam, penanaman nilai-nilai budaya perusahaan dapat diwujudkan dengan mempelajari terlebih dahulu bendabenda budaya yang ada seperti logo perusahaan, seragam yang dipakai, bahasa yang digunakan sehari-hari dan rancangan gedung.

Sebagai Kantor Cabang, logo perusahaan tentu sama dengan logo yang ada di bank BJB Syariah pusat dan juga seragam yang dipakai.

1) Logo perusahaan

Berdasarkan guidence identity, visualisasi dari call name dan logo Bank BJB Syariah dengan bentuk tiga sayapnya menggambarkan interaksi antara bank dengan nasabah, pemegang saham dan masyarakat melalui pemberian layanan yang terbaik, keberpihakan kepada perekonomian yang berbasis kerakyatan serta mampu menjangkau masyarakat sampai ke pelosok.

Tujuannya yaitu untuk memberikan kontribusi yang nyata bagi masyarakat khususnya membantu mendorong perekonomian yang berbasis ekonomi kerakyatan, mampu menjangkau dan memberikan layanan prima kepada nasabah dan stake holder lainya serta mampu meningkatkan kinerja bisnis.

2) Baju Seragam

Bank BJB Syariah KC Bogor mempunyai beberapa baju seragam yang digunakan pada hari-hari tertentu, seperti hari Senin dan Rabu pakaian yang digunakan berwarna merah tua (maroon). Hari Selasa memakai baju berwarna kuning kunyit, Kamis memakai baju produk Bank BJB Syariah berwarna merah tua (maroon) dan memakai kerudung kuning bagi perempuanya dan hari
Jum'at memakai batik. Maknanya yaitu memberikan suatu semangat, keselarasan, kekeluargaan dan juga sebagai daya tarik.

3) Bahasa

Perekrutan karyawan Bank BJB Syariah KC Bogor berasal dari berbagai daerah tentunya bahasa yang digunakan yaitu bahasa Indonesia. Letak kantor Bank BJB Syariah yang berpusat di Jawa Barat tidak menutup kemungkinan mayoritas karyawannya berasal dari daerah tersebut sehingga bahasa kedua yang digunakan ialah bahasa suku Sunda.

\section{Pengorganisasian}

Penentuan pelaksanaan kebijakan yang melibatkan intansi pemerintahan sehingga masyarakat untuk melaksanakan penentuan prosedur tetap kebijakan yang berfungsi sebagai pedoman, petunjuk dan referensi bagi pelaksana dan sebagai pencegah terjadinya kesalah pahaman saat pelaksanaan tersebut menghadapi masalah.

Budaya organisasi pada setiap perusahaan memiliki ciri khas yang berbeda-beda dan tentunya bermanfaat bagi kinerja dan kualitas karyawan pada perusahaan tersebut. Perusahaan tersebut menjadi pembeda antara Bank BJB Syariah KC Bogor dengan bank-bank lainya, dan juga memberi suatu identitas bagi karyawan yang bekerja di perusahaan tersebut. Hal tersebut ditanamkan melalui pendidikan seperti tes tulis seputar nilai-nilai budaya perusahaan yang diselenggarakan oleh kantor pusat dan juga pelatihan yang dilaksanakan dengan hal-hal yang menarik sehingga karyawan termotivasi dan semangat untuk mencapai visi dan misi.

Pernyataan yang disampaikan diatas dapat dilihat bahwa budaya perusahaan cukup memberikan sence 
of identity kepada karyawan sehingga karyawan dapat memahami visi, misi dan juga memberikan semangat bagi karyawan. budaya perusahaan kuat akan menjadi motivator yang kuat juga bagi para karyawanya.

Budaya yang kuat ditentukan oleh pemimpin, bukan ditentukan oleh sistem atau struktur perusahaan. Pemimpin perusahaan harus mampu menetapkan tujuan dan arah dari perusahaan, selain itu pemimpin harus menciptakan dan memelihara lingkungan internal agar karyawan dapat terlibat secara penuh dalam mencapai tujuan-tujuan perusahaan.

Keterlibatan karyawan merupakan faktor penting yang memberikan manfaat yang lebih besar. Dimana karyawan menjadi lebih termotivasi, memberikan komitmen. Karyawan lebih giat dalam melakukan inovasi agar tujuan-tujuan perusahaan tercapai. Karyawan juga memiliki rasa tanggung jawab yang lebih kuat terhadap kewajibanya.

Budaya perusahaan diperkuat dengan adanya kontrol baik internal maupun eksternal. Bank BJB Syariah KC Bogor memiliki pengelola atau pengamatan khusus budaya perusahaan yang dilaksanakan oleh divisi budya perusahaan yang dinamakan change agent. Terdapat juga evaluasi secara berkala untuk melihat efektivitas dan hasil untuk meningkatkan kinerja karyawan. Evaluasi ada yang dilakukan pertiga bulan yaitu KPI (Key Performance Individual) dan juga pertahun yakni LPK (Lembaga Pelatihan dan Kursus). Bank BJB Syariah KC Bogor menggunakan evaluasi per tahun LPK untuk memperkuat budaya perusahaan yang berkinerja tinggi, keterikatan dan kepuasan karyawan melalui par for performance dan kriteria talenta sebagai kenaikan karir.
Bank BJB Syariah KC Bogor juga membangun dan mengelola hubungan dengan nasabah untuk memenuhi dan melampaui ekspetasi dan meningkatkan loyalitas nasabah. Membina hubungan secara formal dan informal serta melakukan evaluasi melalui wawancara, form complaint dan mengunakan mesin CSI (Costumer satifaction index). Hal tersebut berpedoman kepada nilai layanan yang memahami dan memenuhi kebutuhan nasabah, pro aktif dalam pelayanan terhadap nasabah dan juga nilai harmoni yaitu menjaga silaturahmi dan tercipta hubungan yang baik dengan nasabah.

Bank BJB Syariah KC Bogor memiliki penilaian tersendiri mengenai peran budaya perusahaan pernyataan ini diperkuat dengan hasil wawancara dengan pimpinan bank BJB Syariah KC Bogor.

"Definisi budaya perusahaan yaitu nilai-nilai yang dipedomani, dan menjadi cerminan dari kondisi dan citra Bank BJB Syariah KC Bogor").

Berdasarkan pernyataan diatas dapat disimpulkan bahwa peran budaya sangat bermanfaat bagi seluruh karyawan dan juga pimpinan perusahaan. Pemimpin juga harus mengukur keberhasilan perusahaan tidak hanya denga pendekatan finansial, tetapi juga harus mengupayakan semaksimal mungkin terhadap kepuasan nasabah,pemegang saham dan kesejahteraan karyawan perusahaan.

\section{Implikasi}

Implikasi merupakan penerapan atau perwujudan masing-masing tahapan penerapan budaya organisasi yang telah dilaksanakan sebelumnya. Penerapan budaya perusahaan pada Bank BJB Syariah KC Bogor dapat diwujudkan melalui penanaman nilainilai budaya perusahaan dalam kegiatan perusahaan sehari-hari. Hal 
ini diperkuat berdasarkan hasil wawancara dengan pimpinan Bank BJB Syariah KC Bogor.

Penerapan nilai-nilai budaya perusahaan sebenarnya dilakukan dengan aktivitas sehari-hari seperti morning briefing yang dimulai pukul 07.30-09.00 WIB, karyawan harus datang tepat waktu. Morningbriefing tersebut dimulai dengan membaca $\mathrm{Al}$ Qur'an beserta artinya oleh semua karyawan dan pimpinan secara bergilir, dan setelah itu baru pengarahan/evaluasi dari pimpinan untuk semua kegiatan yang akan dilakukan dan yang telah dilakukan kemarin, kemudian dilanjutkan dengan tanggapan/masukan dari karyawan lain untuk memberikan ide-ide atau informasi terkait kegiatan yang dilaksanakan, setelah itu ditutup dengan membaca doa penutup oleh semua karyawan dan pimpinan secara bergilir, terakhir yaitu menyerukan tag line maslahah sembari menggerakan tangan penuh semangat untuk memulai kegiatan. Setiap hari kamis morning brefing ini dilaksanakan dengan berbahasa english,mulai dari pembukaan hingga penutupnya. Kegiatan ini dinamakan 'Kamis English'. Perwujudan nilai-nilai budaya perusahaan pada Bank BJB Syariah KC Bogor yaitu sholat fardhu dilaksanakan diawal waktu, efektivitas penggunaan handphone di jam kerja, setiap ruangan dan meja kerja harus selalu rapi dan bersih. Karyawan melakukan tugas sesuai dengan tupoksinya masing-masing dan berintegritas tinggi, mudah bergaul dan saling bekerja sama, pimpinan yang selalu membimbing dan mengarahkan karyawan dan lain sebagainya

Dari pernyataan yang

disampaikan oleh pimpinan bank BJB Syariah diatas dapat dilihat semua kegiatan yang dilakukan sudah mencakup keenam nilai budaya perusahaan yang ada di Bank BJB Syariah KC Bogor. Dimana nilai tersebut yaitu : Militan diwujudkan dengan adanya karyawan yang bekerja sesuai dengan tupoksinya dan memiliki semangat dan antusias dalam melaksanakan tugas, bekerja keras, kerja cerdas, kerja ikhlas dan kerja tuntas. Amanah yang diterpakan pada karyawan Bank BJB Syariah KC Bogor dapat dilihat pada morning briefing yaitu membaca $\mathrm{Al}$ Qur'an beserta artinya sebelum memulai kegiatan, berdoa bersama, datang tepat waktu. Nilai solusi diwujudkan dengan adanya coaching, mentoring dan conceling. Dilaksanakan per-hari (morning briefing) salah satunya, (weekly report), per-bulan (business review tahunan). Hal tesebut tentu sangat membantu, yaitu terciptanya forum atau diskusi untuk menyelesaikan permasalahan baik masalah pribadi karyawan maupun masalah dalam pekerjaan.

Nilai layanan pada Bank BJB Syariah KC Bogor diwujudkan dengan adanya rutinitas monitoring nasabah secara konsisten dan berkesinambungan dan melayani nasabah dengan ramah dan profesionalitas. Kepuasan nasabah terhadap pelayanan juga akan dievaluasi secara aktif agar Bank BJB KC Bogor mengetahui kekuranganya dan akan selalu diingatkan sesuai dengan kebutuhan nasabah.

Nilai harmoni diwujudkan dengan adanya hubungan yang baik sesama karyawan, hubungan yang baik dengan nasabah, dan hubungan yang baik dengan pimpinan, dan adanya sikap saling mendukung dan menghargai sesama dalam bekerja.

Nilai holistik diwujudkan dengan adanya team work yang baik, dan selalu mementingkan kepentingan bersama, saling membantu satu sama 
lain untuk mencapai kinerja yang unggul

Nilai-nilai budaya diatas secara keseluruhan telah diterapkan dengan cukup baik pada karyawan Bank BJB Syariah KC Bogor yakni nilai militan, amanah, solusi, layanan, harmoni serta holistik. Sehingga berdampak pada keseharian para karyawan di kantor menjadi lebih semangat, lebih displin dan tanggung jawab, memiliki hubungan baik antar karyawan serta hubungan yang baik denga atasan, meningkatnya kepercayaan dan loyalitas nasabah terhadap Bank BJB Syariah KC Bogor, hal tersebut terbukti dengan adanya penghargaanpenghargaan yang didapatkan oleh karyawannya seperti costumer service terbaik. Tidak hanya itu, Bank BJB Syariah KC Bogor juga mendapatkan penghargaan sebagai KC terbaik yang diukur dan dinilai dari kinerja KC dengan Balance Scorecard, yang mana didalamnya terdapat target (visi misi), Action Plan dan Key Performance Individual (KPI).

\section{KESIMPULAN DAN IMPLIKASI}

Berdasarkan hasil
yang penelitian
menggunakan lakukan $\begin{array}{r}\text { dengan } \\ \text { kualitatif }\end{array}$
deskriptif dapat ditarik kesimpulan
sebagai berikut:

1. Terdapat enam nilai Corporate Culture yang menjadi pedoman bagi setiap karyawan dalam melaksanakan pekerjaan. Nilai-nilai tersebut yaitu MASLAHAH (Militan, Amanah, Solusi, Layanan, Harmoni, dan Holistik).

2. Implementasi nilai-nilai budaya perusahaan pada karyawan Bank BJB Syariah KC Bogor yaitu sosialisasi. Sosialisasi yang dilakukan mulai awal pemilihan calon karyawan Bank BJB Syariah sampai karyawan yang sudah bekerja, dibuatkannya buku saku agar karyawan mudah mengakses hal-hal yang boleh dilakukan dan yang tidak boleh dilakukan dalam suatu kegiatan. Kemudian diwujudkan dalam kegiatan seharihari seperti morning briefing yang didalamnya terdapat nilai amanah, nilai harmoni dan nilai solusi, selain itu nilai militan, layanan dan holistic pun diwujudkan saat dilaksanakannya dan misi perusahaan.

Penelitian ini diharapkan dapat memberikan manfaat umumnya kepada intansi yang terkait, pengenmabng penelitan yang sama dan khusus nya kepada penulis.

\section{DAFTAR PUSTAKA}

Naskah jurnal atau abstrak

Hajaroh M. (2005). Paradigma, Pendekatan Dan Metode

Penelitian Fenomenologi. Dosen

Program Studi Kebijakan

Pendidikan FIP UNY, bidang keahlian Penelitian dan Evaluasi Pendidikan. , 13.

Akib, H. (2010). Implementasi

Kebijakan. Journal Administrasi Publik Vol 1 No. 1, 2.

H.M, M. M. (2014). Sistem Nilai dan Pandangan Hidup Serta Relasinya Dengan Ilmu pengetahuan. wardah No. 8, 64 .

Harding, D., N, E., \& Fitriana, E. (2015). N Universitas Nilai-nilai Personal Karyawan Universitas Islam Bandung. Psychology Forum UMM ISBN: 978-979-796324-8, 100.

Jamin, I., Zamsyah, I., \& Anisa, I. (2007). Corporate Culture And Health Care Organization. Journal Community of Health vOL. 13 No. 1 , 4-5. 
Latifah, U., \& Haryani, S. (2014). Pengaruh Motivasi, Pengawasan Dan Budaya Kerja Terhadap Produktivitas Kerja Kariawan Perusahaan Pengecoran "Sp" Yogyakarta. Telaah Bisnis Volume 15, 97.

Lorincova, S., \& Hitko, M. B. (2016). Buadaya Perusahaan di Slovakia Sebagai Faktor Kualitas HRM. jurnal internasional untuk Kualitas HRM.

Lukman, M. B., \& Sunarti, e. (2015).

Pengaruh Penerapan Perusahaan Terhadap Motivasi Kerja Dan Kinerja Karyawan Di Pt Rekayasa Industri. Aplikasi Bisnis Manajemen (JABMAN) vOL. 1 No 1, 2.

Moeljono, D. (2005). Good Corporate Culture. Benefit, Vol 9 No 2, 155.

Perbawasari, S., \& Setianti, Y. (2013). Komunikasi Dalam Transformasi Budaya Perusahaan. Jurnal Komunikasi Vol.16 No 1, 2.

Prajitisari, E. B., \& A.S, T. (2009). Budaya Korporat Dan Produktivitas Kerja Karyawan Pt. Bank Rakyat Indonesia (Persero Tulungangung). Wacana Vol.12 no 2, 232.

Syihabudin. (2007). Pengaruh Budaya Dan Citra Perusahaan Terhadap Komitmen Organisasional Karyawan. Moderenisasi Vol. 3 No 2, 73.

Vasquez, l., \& Gonjales. (2015). budaya organisasi dari teori Edgar studi fenomenologis. majalah clio amerika ISSN : 1909-941 XVol 19 No 17.

Wibowo, A. S. (2014). Pengaruh Budaya Organisasikepuasan Kerja
Dan Gaya Kepemimpinan Terhadap Kinerja Kariawan. Jurnal Manajemen Bisnis, 2.

Widuri, R., \& Paramita, A. (2007). Analisis Hubungan Peranan Budaya Perusahaan Terhadap Penerapan Good Corporate Governance Pada PT Aneka Tambang TBK. Journal The winner Vol. 8 No. 2

\section{Buku}

Djokosantoso, M. (2003). Budaya Korporat dan Keunggulan Korporasi. Jakarta: Elex media.

Drajat, Z. (1984). Dasar-dasar Agama Islam. Jakarta: CV Kuning Mas.

Sautlan, L. M. (2018). Aset Bank Syariah Tumbuh 20,65 per Februari. Jakarta: Kontan.co.id.

Sitanggang, F., \& Hardjo, R. (2014). Penguatan Budaya Organisasi di Kantor Pusat Bank Indonesia. Public Administration, 2.

Suryana, T. (1996). Pendidikan Agama Islam untuk Perguruan tinggi. Bandung: Tiga Mutiara.

Tasmara, T. (2002). Membudayakan Etos Kerja Islami. Jakarta: Gema Insani.

Pandawati, S. (2007). Kajian Filosofis dan Nilai-nilai Islam dalam Hikayat Raja Rahib. Semarang : Universitas Negeri Semarang.

Komang, W. (2009). Perilku Keorganisasian. Yogyakarta: Graha Ilmu .

Wirawan. (2007). Budaya dan iklim organisasi Teori Aplikasi dan penelitian. Jakarta. 